\title{
Coconut sap sugar and syrup: a promising functional food/ingredient
}

\author{
Trinidad P. Trinidad*, Aida C. Mallillin, Ennata M. Avena, Regina G. Rodriguez, \\ Melissa S. Borlagdan, Kristine Bernadette B. Cid, E Kristine T. Biona \\ Food and Nutrition Research Institute, Department of Science and Technology \\ Bicutan, Taguig City, 1631 Metro Manila, Philippines
}

\begin{abstract}
Sugars are not created equal. They may be classified as simple and complex. Simple sugars are readily digestible in the small intestine while complex sugars are not. Thereby, in terms of glucose response, complex sugar may be a good sugar substitute and may have a significant role in the proper control and management of diabetes mellitus and in the prevention for risk of obesity. The study aimed to determine coconut sap sugar and syrup as a promising functional food/ingredient. Coconut sap sugar and syrup were characterized in terms of nutrient composition, dietary fiber/sugar composition and its fermentability characteristics, and physicochemical and microbiological properties using standard methods. Results showed that both products have acceptable water activity with time. Salmonella and coliform are within the acceptance criteria of the Philippine National Standards. The color was attributed to the effects of temperature, relative humidity and $\mathrm{pH}$. The moisture of coco sugar was within CODEX Standards (1.7$1.8 \mathrm{~g} / 100 \mathrm{~g}$ ). Significant amounts of minerals and vitamins were obtained. Both products contained sucrose, glucose, fructose and mannose. No dietary fiber was detected from coconut sap sugar but has significant amounts of inulin $(4.7 \mathrm{~g} / 100 \mathrm{~g})$. Coconut sap syrup has both dietary fiber and inulin. Fermentable inulin produced short chain fatty acids with propionate $>$ acetate $>$ butyrate $(p<0.05)$. The significant amounts of inulin and propionate are added values of coconut sap sugar/syrup and may be considered as a promising functional food/ingredient.
\end{abstract}

Keywords: coconut sap sugar/syrup, functional food, nutrient composition, inulin

\section{INTRODUCTION}

Carbohydrates are commonly referred to as "sugars". However, all sugars are not created equal. Sugars are classified according to the number of glucose or degree of glucose polymerization. Simple sugar or sucrose contains both one unit of glucose and one unit

*To whom correspondence should be addressed trinidadtp@yahoo.com.ph of fructose. Oligosaccharides contain 3-9 glucose units and are termed complex carbohydrates/sugars and may also contain fructose e.g. fructo-oligosaccharides. Some sugar polymers that contain fructose may contain greater than ten glucose polymers e.g. inulin, and considered as dietary fiber, a nonstarch polyssacharide. Simple sugars are readily digestible in the small intestine while complex sugars are not. They are slowly digested and metabolized in the large intestine 
and produce short chain fatty acids similar to dietary fiber. Slowly digested sugars are low glycemic index food. Complex sugar may be a good sugar substitute and may have a significant role in the proper control and management of diabetes mellitus and in the prevention for risk of obesity.

The International Diabetes Federation estimated that in 2015 there are 415 million people worldwide believed to have diabetes [1]. Experts projected that by 2040, this figure will rise to 642 million. An estimated $50 \%$ of people worldwide have diabetes but are not aware they have it, and up to $91 \%$ of these have type- 2 diabetes mellitus. The Philippines has the $10^{\text {th }}$ highest incidence of diabetes worldwide [1]. An estimated six million Filipinos know they have diabetes and another estimated six million who have diabetes but do not know they have it. Health experts believe many more have impaired glucose tolerance (IGT) and are prone to diabetes.

Coconut sap sugar and syrup come from the watery sap that drips from cut flower buds or inflorescence of the coconut tree. The sap is collected each morning and afternoon and boiled in huge woks known locally as 'calja' until only the coco sugar remains. Each tapper can produce 2-4 L a day per coconut tree and can produce up to eight gallons of sap daily. Coconut sugar has great potential as a natural and cheaper alternative for synthetic sweeteners derived from "natural" ingredients. At present, a kilogram of coco sugar requires around two gallons of coconut sap while a gallon of the so-called coco honey calls for around seven gallons of sap. Present production output from some two hectares of coconut with 300 hybrid coconut varieties has reached 3.5 metric tons of coconut sugar and 200 five gallon of coconut honey. In Asian markets, coconut sugar is already available in India and Thailand although they are used primarily as confectionery sugar for making sweets and desserts.
A study done on coconut sap sugar and syrup found that both products have low glycemic index (GI) of 35 and 39, respectively [2]. Low GI foods are health beneficial because they can control rise in blood glucose and may have a significant role for risk of diabetes mellitus and obesity. This was a major turning point in the industry as it can offer a natural sweet alternative for diabetics.

The sugar components and the volatile components of coconut sap sugar and coconut sap syrup have been studied [3-5]. However, information about the nutrient composition, physicochemical and microbiological properties, complex sugar, dietary fiber and its fermentability in the colon are scarce. Retention studies about the nutrients that they contain are lacking and so are studies on the stability of the nutrients and the status of physicochemical properties during long periods of storage. The study determined coconut sap sugar and syrup as a promising functional food/ingredient.

\section{EXPERIMENTAL}

Food sampling. Three batches of coconut sap sugar and syrup were used in the study. The coconut sap sugar was homogenized and sieved at 850 micro particle size in a 20 mesh sieve.

Likewise, the coconut sap syrup was homogenized.

Physicochemical analysis. The following were the methods used for the physicochemical analyses of the Coconut Sap Sugar and Coconut Sap Syrup: The pH of coconut sap sugar and coconut sap sugar syrup was measured using AOAC Method 981.12 [6] with some modifications. The $\%$ Brix was measured using the Atago PR-201 digital refractometer. The $\%$ titratable acidity was determined using AOAC Method 935.57 [6]. The color was measured by Konica Minolta Chromameter, 
providing a result in CIE Lab system (L*(lightness-darkness), a*(rednessgreenness) and $b^{*}$ (yellowness-blueness). e. Water activity, $a W$ was measured using Novasina water activity meter.

Nutrient analyses. Nutrient analyses were done immediately after sample homogenization of coconut sap sugar and syrup. Moisture content was determine by means of vacuum drying (AOAC Method 925.45A [6]) for coconut sap sugar and vacuum drying on quartz sand (AOAC Method 925.45D [6]) for coconut sap syrup. For both products: ash content was determined using AOAC Method 925.49A [6]; total fat, using acid hydrolysis (Tecator) method; and protein, using the Automated Kjeldahl Method (Buchi) Analyzer. Available carbohydrate was computed by difference: Carbohydrates $=100$ (Moisture +Ash + Total Fat + Protein).

Total Sugars were determined using the LaneEynon constant volume volumetric method (AOAC Method 968.28 [6]). Minerals (calcium, iron, potassium, sodium, and zinc) were determined using modified AOAC Method 985.35 [6]. Temperature used for ashing was $500^{\circ} \mathrm{C}$. Vitamin $\mathrm{C}$ content was determined using AOAC Method 967.21 [6].

Microbiological analyses. The following analyses were done: Aerobic Plate Count based on FDA-BAM-3, 2001[7]; Coliform Count based on FDA-BAM-4, 2001 [7]; Mold and Yeast Count based on FDA-BAM-18, 2001[7]; and, Salmonella sp. based on FDA-BAM-5, 2007 [7].

Dietary fiber/inulin analysis. Dietary fiber from coconut sap sugar and syrup was determined using the AOAC Method 991.4 [6], while inulin analysis was done at the Medallion Laboratories in Minessota, U.S.A. The fermentation of dietary fiber and inulin was determined by the method of McBurney and Thompson [8].
Sugar composition. The sugar composition of coconut sap sugar/syrup was determined using gas chromatography according to the method of Brunton et al. [9] and Ruiz-Matute et al. [10].

\section{Results}

The Philippine National Standards [11] has defined the classification of coconut sap sugar with the degree of color and water activity values as two of the criteria. The light colored coco sugar class is considered to be the premium grade. The samples of coconut sap sugar received for the study varied in color from cream (Batch 3) to dark brown (Batch 1) to slightly light dark brown (Batch 2).

The water activity $\left(a_{w}\right)$ is defined as the amount of water in the product that is available for the growth of microorganism. According to the Philippine National Standard for coconut sap sugar grading [11], the water activity $\left(\mathrm{a}_{\mathrm{w}}\right)$ of coconut sap sugar ranged from 0.5 to 0.8 . The results of the water activity analyses conducted for the three batches of coco sugar showed a range $0.4-0.5$ for the coco sugar (Table 1). This means that coco sugar passed the requirement for water activity parameter. No available Philippine standard on coconut sap syrup was defined. Using the same standard for coconut sap sugar, the properties of the three batches of coco syrup were evaluated. Using the water activity criteria of the PNS as basis, the results for the coco syrup of 0.6 , conformed with the standard (Table 1).

The results of the physicochemical analysis of coconut sap sugar and coconut sap syrup are given in Table 1. The titratable acid is expressed as lactic acid, which is formed from the fermentation of the reducing sugars formed during the hydrolysis of the sugars in the coconut sap. The lactic acid leads to the decrease in the $\mathrm{pH}$, an increase in the hydrogen ion concentration/titratable acids. 
Table 1. Physico-chemical characteristics of coconut sap sugar and syrup (Mean \pm SEM; $n=3$ )

\begin{tabular}{l|c|c|c|c|c|c}
\hline \multirow{2}{*}{ Analysis } & \multicolumn{3}{c|}{ Coconut Sap Sugar } & \multicolumn{3}{c}{ Coconut Sap Syrup } \\
\cline { 2 - 7 } & Month 0 & Month 3 & Month 6 & Month 0 & Month 3 & Month 6 \\
\hline \hline $\mathrm{pH}$ & $5.79 \pm 0.01^{\mathrm{x}}$ & $5.40 \pm 0.01^{\mathrm{y}}$ & $5.11 \pm 0.01^{\mathrm{z}}$ & $4.45 \pm 0.01^{\mathrm{x}}$ & $4.33 \pm 0.01^{\mathrm{y}}$ & $4.28 \pm 0.00^{\mathrm{x}}$ \\
\hline${ }^{\circ}$ Brix & $98.9 \pm 0.06^{\mathrm{x}}$ & $98.4 \pm 0.25^{\mathrm{x}}$ & $97.6 \pm 0.21^{\mathrm{y}}$ & $80.3 \pm 0.17^{\mathrm{x}}$ & $80.1 \pm 0.09^{\mathrm{x}}$ & $79.6 \pm 0.17^{\mathrm{y}}$ \\
\hline Water Activity & $0.44 \pm 0.00^{\mathrm{z}}$ & $0.50 \pm 0.00^{\mathrm{y}}$ & $0.54 \pm 0.00^{\mathrm{x}}$ & $0.64 \pm 0.00^{\mathrm{y}}$ & $0.64 \pm 0.00^{\mathrm{y}}$ & $0.65 \pm 0.00^{\mathrm{x}}$ \\
\hline $\begin{array}{l}\text { Total Titratable Acid, } \\
\text { \% Lactic Acid }\end{array}$ & $0.3 \pm 0.00^{\mathrm{z}}$ & $0.4 \pm 0.00^{\mathrm{y}}$ & $0.5 \pm 0.01^{\mathrm{x}}$ & $0.7 \pm 0.00^{\mathrm{y}}$ & $0.7 \pm 0.01^{\mathrm{y}}$ & $0.8 \pm 0.00^{\mathrm{x}}$ \\
\hline Color (L) & $63.50 \pm 0.00^{\mathrm{x}}$ & $57.42 \pm 0.00^{\mathrm{y}}$ & $53.38 \pm 0.01^{\mathrm{z}}$ & $19.96 \pm 0.06^{\mathrm{x}}$ & $17.87 \pm 0.00^{\mathrm{y}}$ & - \\
\hline Color (a*) & $7.50 \pm 0.01^{\mathrm{z}}$ & $8.47 \pm 0.01^{\mathrm{y}}$ & $9.08 \pm 0.01^{\mathrm{x}}$ & $7.72 \pm 0.06^{\mathrm{y}}$ & $8.26 \pm 0.02^{\mathrm{x}}$ & - \\
\hline Color (b*) & $28.28 \pm 0.01^{\mathrm{x}}$ & $24.02 \pm 0.00^{\mathrm{z}}$ & $25.85 \pm 0.01^{\mathrm{y}}$ & $-1.44 \pm 0.11^{\mathrm{x}}$ & $-1.67 \pm 0.01^{\mathrm{y}}$ & - \\
\hline Viscosity & - & - & - & $12,110 \pm 6^{\mathrm{x}}$ & $8,527 \pm 327^{\mathrm{z}}$ & $9,490 \pm 81^{\mathrm{y}}$ \\
\hline
\end{tabular}

$\mathrm{x}, \mathrm{y}, \mathrm{z}$ denote significant differences between time.

Table 2. Proximate analysis of coconut sap sugar and syrup (g/100 g Sample, Mean \pm SEM)

\begin{tabular}{l|c|c|c|c|c|c}
\hline \multirow{2}{*}{ Analysis } & \multicolumn{3}{|c|}{ Coconut Sap Sugar } & \multicolumn{3}{c}{ Coconut Sap Syrup } \\
\cline { 2 - 7 } & Month 0 & Month 3 & Month 6 & Month 0 & Month 3 & Month 6 \\
\hline \hline Moisture & $1.7 \pm 0.02^{\mathrm{y}}$ & $2.2 \pm 0.02^{\mathrm{x}}$ & $2.5 \pm 0.02^{\mathrm{x}}$ & $18.1 \pm 0.18^{\mathrm{x}}$ & $18.2 \pm 0.11^{\mathrm{x}}$ & $18.1 \pm 0.13^{\mathrm{x}}$ \\
\hline Protein & $1.2 \pm 0.02^{\mathrm{x}}$ & $1.1 \pm 0.01^{\mathrm{y}}$ & $1.1 \pm 0.01^{\mathrm{y}}$ & $1.0 \pm 0.00^{\mathrm{x}}$ & $1.0 \pm 0.01^{\mathrm{x}}$ & $1.0 \pm 0.01^{\mathrm{x}}$ \\
\hline Fat & $0.1 \pm 0.02^{\mathrm{x}}$ & $0.1 \pm 0.01^{\mathrm{x}}$ & $0.1 \pm 0.01^{\mathrm{x}}$ & $0.1 \pm 0.01^{\mathrm{y}}$ & 0.0 & $0.2 \pm 0.02^{\mathrm{x}}$ \\
\hline Carbohydrates & $94.9 \pm 0.09^{\mathrm{x}}$ & $94.4 \pm 0.21^{\mathrm{x}}$ & $94.1 \pm 0.17^{\mathrm{x}}$ & $79.0 \pm 0.19^{\mathrm{x}}$ & $79.2 \pm 0.20^{\mathrm{x}}$ & $79.1 \pm 0.21^{\mathrm{x}}$ \\
\hline Total Sugar & $94.1 \pm 0.48^{\mathrm{x}}$ & $92.4 \pm 0.42^{\mathrm{y}}$ & $91.0 \pm 0.30^{\mathrm{z}}$ & $67.6 \pm 0.16^{\mathrm{x}}$ & $67.1 \pm 0.30^{\mathrm{x}}$ & $64.5 \pm 0.30^{\mathrm{y}}$ \\
\hline Ash, g/100g & $2.2 \pm 0.01^{\mathrm{x}}$ & $2.2 \pm 0.03^{\mathrm{x}}$ & $2.1 \pm 0.02^{\mathrm{y}}$ & $1.7 \pm 0.01^{\mathrm{x}}$ & $1.7 \pm 0.00^{\mathrm{x}}$ & $1.6 \pm 0.00^{\mathrm{y}}$ \\
\hline
\end{tabular}

$\mathrm{x}, \mathrm{y}, \mathrm{z}$ denote significant differences between time.

Table 3. Minerals and vitamin $C$ content of coconut sap sugar and syrup (mg/100g, Mean \pm SEM)

\begin{tabular}{l|c|c|c|c|c|c}
\hline \multirow{2}{*}{ Analysis } & \multicolumn{3}{|c|}{ Coconut Sap Sugar } & \multicolumn{3}{c}{ Coconut Sap Syrup } \\
\cline { 2 - 7 } & Month 0 & Month 3 & Month 6 & Month 0 & Month 3 & Month 6 \\
\hline \hline Calcium & $8 \pm 0.07^{\mathrm{x}}$ & $8 \pm 0.02^{\mathrm{x}}$ & $8 \pm 0.14^{\mathrm{x}}$ & $2 \pm 0.05^{\mathrm{x}}$ & $1 \pm 0.07^{\mathrm{y}}$ & $2 \pm 0.03^{\mathrm{x}}$ \\
\hline Iron & $0.6 \pm 0.01^{\mathrm{x}}$ & $0.6 \pm 0.01^{\mathrm{x}}$ & $0.5 \pm 0.02^{\mathrm{y}}$ & $0.4 \pm 0.02^{\mathrm{x}}$ & $0.4 \pm 0.02^{\mathrm{x}}$ & $0.4 \mathrm{v} 0.01^{\mathrm{x}}$ \\
\hline Potassium & $1075 \pm 9.47^{\mathrm{x}}$ & $954 \pm 9.52^{\mathrm{y}}$ & $957 \pm 9.40^{\mathrm{y}}$ & $632 \pm 6.22^{\mathrm{x}}$ & $621 \pm 7.65^{\mathrm{xy}}$ & $609 \pm 8.75^{\mathrm{y}}$ \\
\hline Sodium & $112 \pm 5.25^{\mathrm{x}}$ & $106 \pm 2.12^{\mathrm{y}}$ & $99 \pm 1.84^{\mathrm{z}}$ & $126 \pm 7.53^{\mathrm{x}}$ & $122 \pm 2.42^{\mathrm{x}}$ & $110 \pm 3.16^{\mathrm{y}}$ \\
\hline Zinc & $0.1 \pm 0.00^{\mathrm{x}}$ & $0.1 \pm 0.00^{\mathrm{x}}$ & $0.1 \pm 0.00^{\mathrm{x}}$ & $0.2 \pm 0.00^{\mathrm{x}}$ & $0.1 \pm 0.00^{\mathrm{y}}$ & $0.1 \pm 0.00^{\mathrm{y}}$ \\
\hline Vitamin C & $44 \pm 0.76^{\mathrm{x}}$ & $23 \pm 0.23^{\mathrm{y}}$ & $16 \pm 0.37^{\mathrm{z}}$ & $30 \pm 0.57^{\mathrm{x}}$ & $24 \pm 0.24^{\mathrm{y}}$ & $19 \pm 0.42^{\mathrm{z}}$ \\
\hline
\end{tabular}

$\mathrm{x}, \mathrm{y}, \mathrm{z}$ denote significant differences between time.

The microbiological characteristics of the coconut sap sugar and coconut sap syrup remain as the most important parameters to be evaluated. Aside from being food safety indicators, the presence of microorganism may initiate fermentation of the product and is expected to alter the flavor, aroma and the overall shelf life qualities of the coconut sap products.

The coco sugar passed the limits set for Salmonella $\mathrm{sp} . / 25 \mathrm{~g}$ which should be negative and for the coliform count, MPN/g which should be less than $10 \mathrm{CFU} / \mathrm{g}$. However, for the 
Aerobic Plate Count which should be less than $10 \mathrm{CFU} / \mathrm{g}$ and for the mold and yeast, which should be less than $10 \mathrm{CFU} / \mathrm{g}$, the coco sugar did not pass these criteria. The results of Salmonella and coliform tests for the coconut sap sugar were within the acceptance criteria of the PNS. However, the Aerobic Plate Count which was $<10$ to $<250 \mathrm{CFU} / \mathrm{g}$ exceeded the limit set by the PNS. These results indicate the need to closely monitor certain steps in the production of coconut sap sugar/syrup.

Table 2 summarizes the results obtained for the proximate analysis of the coconut sap sugar and the coconut sap syrup. No criteria for moisture content of coco sugar were specified in the Philippine National Standard. Results from the Philippine Coconut Authority showed $2.2 \%$ moisture content for the coco sugar. Based on CODEX STAN 212-1999 [12], the soft brown sugar has a moisture content of $<4.5 \% \mathrm{~m} / \mathrm{m}$. The moisture of the three batches of coco sugar ranged from $1.7 \mathrm{~g}$ to $1.8 \mathrm{~g} / 100 \mathrm{~g}$ showing the conformance to the CODEX Standard.

The ash content obtained for the coco sugar samples ranged from $2.1 \mathrm{~g}$ to $2.3 \mathrm{~g} / 100 \mathrm{~g}$ while for coco syrup a mean value of $1.7 \mathrm{~g} / 100 \mathrm{~g}$ was obtained. Results showed a total sugar content ranging from $93.6 \mathrm{~g}$ to $94.8 \mathrm{~g} / 100 \mathrm{~g}$. This resulted to a calculated range of $81-96 \mathrm{~g} / 100 \mathrm{~g}$ total sugar. The total sugar content of coconut sap sugar and syrup were within the computed acceptable range.

For the nutrient analysis the results obtained were consistent with the literatures. The measurement of the dietary fiber could not be carried out since a very small amount of residue was obtained after drying, defatting and getting the sugar out should amount to approximately one gram to be able to do the analysis. The fat content of the products were found to be insignificant.
Table 3 presents the results of the analysis for minerals and vitamin C. Coconut sap sugar and syrup showed significant amounts of potassium and vitamin $\mathrm{C}$ with coconut sap sugar significantly greater than that of the syrup (Table $3 ; p<0.05$ ). Although potassium and vitamin $C$ significantly decreased from 0 to 6 months, it still remain to be good sources of both nutrients (Table $3 ; p<0.05$ ). Both products showed significant decreasing trends in vitamin C from 0-3 months to 6 months which may be due to exposure in light and hydrolysis of vitamin $\mathrm{C}$.

The dietary fiber and inulin content of coconut sap sugar and syrup were analyzed at 0 time (Table 4). As shown in previous results, no dietary fiber was detected from coconut sap sugar but has significant amount of inulin while coconut sap syrup contained both dietary fiber and inulin.

The sugar composition of coconut sap sugar and syrup were analyzed individually using gas chromatography (Table 5). Increasing amounts with time (0-6 months) were obtained for sucrose and mannose but not fructose and glucose for coconut sap sugar. Similar results were obtained for coconut sap syrup.

Significant amounts of short chain fatty acids were obtained after fermentation of coconut sap sugar and syrup with coconut sap sugar significantly greater than that of coconut sap syrup (Table $6 ; p<0.05$ ). In general, there was an increasing trend in the production of short

\section{Table 4. Dietary fiber and inulin content of coconut sap sugar/syrup $(\mathrm{g} / \mathbf{1 0 0} \mathrm{g})$}

\begin{tabular}{l|c|c}
\hline & $\begin{array}{c}\text { Coconut Sap } \\
\text { Sugar }\end{array}$ & $\begin{array}{c}\text { Coconut Sap } \\
\text { Syrup }\end{array}$ \\
\hline \hline Dietary Fiber & 0.00 & 0.60 \\
\hline Inulin* & 4.57 & 0.50 \\
\hline
\end{tabular}

*Analyzed at Medallion Laboratories, Minnesota, U.S.A. 
Table 5. Sugar composition of coconut sap sugar and syrup (mg/100 g Sample Mean \pm SEM)

\begin{tabular}{l|c|c|c|c|c|c}
\hline \multirow{2}{*}{$\begin{array}{c}\text { Sugar } \\
\text { Composition }\end{array}$} & \multicolumn{3}{|c|}{ Coconut Sap Sugar } & \multicolumn{3}{c}{ Coconut Sap Syrup } \\
\cline { 2 - 7 } & Month 0 & Month 3 & Month6 & Month 0 & Month 3 & Month 6 \\
\hline \hline Sucrose & $83.18 \pm 0.77^{\mathrm{y}}$ & $84.48 \pm 0.96^{\mathrm{y}}$ & $90.50 \pm 1.14^{\mathrm{x}}$ & $36.02 \pm 1.02^{\mathrm{y}}$ & $35.85 \pm 0.34^{\mathrm{y}}$ & $38.96 \pm 0.53^{\mathrm{x}}$ \\
\hline Fructose & $3.69 \pm 0.27^{\mathrm{x}}$ & $3.61 \pm 0.15^{\mathrm{x}}$ & $2.89 \pm 0.04^{\mathrm{y}}$ & $15.45 \pm 0.51^{\mathrm{x}}$ & $15.39 \pm 0.36^{\mathrm{x}}$ & $15.57 \pm 0.30^{\mathrm{x}}$ \\
\hline Glucose & $11.45 \pm 0.22^{\mathrm{x}}$ & $9.40 \pm 0.12^{\mathrm{y}}$ & $10.97 \pm 0.24^{\mathrm{x}}$ & $14.03 \pm 0.45^{\mathrm{x}}$ & $14.00 \pm 0.28^{\mathrm{x}}$ & $10.74 \pm 0.70^{\mathrm{y}}$ \\
\hline Mannose & $2.78 \pm 0.17^{\mathrm{y}}$ & $0.51 \pm 0.07^{\mathrm{z}}$ & $3.90 \pm 0.22^{\mathrm{x}}$ & $3.91 \pm 0.38^{\mathrm{z}}$ & $5.35 \pm 0.34^{\mathrm{x}}$ & $4.81 \pm 0.11^{\mathrm{y}}$ \\
\hline $\mathrm{x}, \mathrm{y}, \mathrm{z}$ denote significant differences between time
\end{tabular}

$\overline{x, y, z}$ denote significant differences between time.

Table 6. Short chain fatty acid produced from fiber fermentation of coconut sap sugar and syrup (mg/g Sample, Mean \pm SEM)

\begin{tabular}{|c|c|c|c|c|c|c|}
\hline \multirow{2}{*}{$\begin{array}{c}\text { Short Chain } \\
\text { Fatty Acid }\end{array}$} & \multicolumn{3}{|c|}{ Coconut Sap Sugar } & \multicolumn{3}{|c|}{ Coconut Sap Syrup } \\
\hline & Month 0 & Month 3 & Month 6 & Month 0 & Month 3 & Month 6 \\
\hline Acetic Acid & $14.05 \pm 0.35^{\mathrm{y}}$ & $\overline{77.14 \pm 0.71^{z}}$ & $18.01 \pm 0.55^{\mathrm{x}}$ & $8.96 \pm 0.76^{\mathrm{y}}$ & $6.29 \pm 0.42^{z}$ & $16.45 \pm 0.97^{\mathrm{x}}$ \\
\hline Propionic Acid & $135.7 \pm 3.6^{\mathrm{z}}$ & $187.70 \pm 1.05^{\mathrm{x}}$ & $141.15 \pm 0.27^{\mathrm{y}}$ & $105.6 \pm 6.9^{z}$ & $155.80 \pm 1.74^{x}$ & $118.76 \pm 1.04^{\mathrm{y}}$ \\
\hline Butyric Acid & $7.28 \pm 0.44^{\mathrm{Z}}$ & $9.98 \pm 0.43^{y}$ & $19.56 \pm 1.46^{\mathrm{x}}$ & $1.71 \pm 0.16^{\mathrm{Z}}$ & $3.50 \pm 0.17^{y}$ & $18.90 \pm 0.90^{\mathrm{x}}$ \\
\hline
\end{tabular}

chain fatty acids with time (0-6 months). It was observed that both coconut sap sugar and syrup has significantly greater propionate than acetate and butyrate.

\section{Discussion}

Data on the colors of the samples validates the observation that coco sugar vary in color. This is probably one of the reasons why the sugars are graded. There are several factors responsible for the color differences; a) location and type of soil where the coconut tree is planted; b) the climatic conditions in the plantation; c) the age and variety of the tree, and d) the procedure used in processing including the temperature and length of time of cooking. According to the Coconut Sugar Philippines [13], coconut sap sugar from coconut trees planted in the mountains are normally light brown shade in color than the same coconut tree variety planted near the sea which are observed to give darker brown shade of color for the coconut sap sugar. The color change may also be attributed to the effects of temperature, relative humidity and $\mathrm{pH}$ of the samples during storage.

It is said that the high temperature used in cooking the sap can kill some but not all microorganism especially the yeast. This is one area for future consideration. Another important observation that warrants special attention is the type of packaging material used. Perhaps there should be a standard pore size for the plastic container which would not permit entrance of the microorganism. This suggests a need for ensuring a really airtight procedure for sealing the container.

The increase in moisture content observed in the study can be rationalized by the absorption of the atmospheric moisture, the type of plastic material used as packaging and efficiency of the sealing machine used in packing of sugar and syrup. Also, the increase in moisture content could be the reason seen in the decrease in the total sugar content. The moisture may have initiated the hydrolysis of the sucrose to glucose and fructose. This 
hydrolytic process in turn accounts for the decrease in the solid concentration expressed as ${ }^{0}$ Brix (Table 1 ).

Coconut sap sugar and syrup has been shown to be excellent sources of potassium and vitamin $\mathrm{C}$. The combined action of potassium and the significant amounts of propionate produced from fermentation of inulin in vitro may be promising in the prevention for risk of coronary heart disease. Propionate may inhibit cholesterol synthesis by controlling the limiting enzyme HMG Co A-reductase that converts acetoacetate to mevalonate down to the formation of cholesterol [14]. Potassium has been shown to lower blood pressure. Previous study has shown that coconut sap sugar and syrup may be recommended for use in humans for prevention for risk of diabetes mellitus and cardiovascular diseases because of its low glycemic index [2].

\section{Conclusion}

The significant amounts of potassium, vitamin $\mathrm{C}$, inulin and its product of fermentation (propionate) are added values of coconut sap sugar/syrup and may be considered as a promising functional food/ingredient. Potassium and propionate produced from inulin fermentation in both coconut sap sugar and syrup may have a promising role in the prevention for risk of coronary heart disease. The inulin and dietary fiber content of coconut sap sugar and syrup, respectively, may contribute in the slow release of glucose after its consumption and may play an important role in the proper control and management of diabetes mellitus.

\section{ACKNOWLedgments}

The authors thanked the following FNRI staff for their technical assistance: Dr. Rosario R. Sagum, Ms. Teresita R. Portugal, Julita G. Ardena, Marco P. de Leon, Mark Ryan Q. Ibardaloza, Zoilo B. Villanueva, Carlito J.
Magno, Kevin Ray P. Ayag, Prudencio E. Adona Jr., and Romnick A. Enriquez. The coconut sap sugar and syrup were supplied by FNRI Industry Partner, Ms. Lalaine V. Abonal of E-Asia Outsourcing and Marketing, Makati City, Philippines. The project was funded by the Philippine Council for Industry, Energy and Emerging Research and Development of the Department of Science and Technology (PCIERRD-DOST). There is no conflict of interest between authors and coordinating government agency and industry.

\section{REFERENCES}

[1] IDF Diabetes Atlas, $7^{\text {th }}$ Edition. (Brussels, Belgium: International Diabetes Federation, 2015).

[2] Trinidad TP, Mallillin AC, Sagum RS, \& Encabo RR. Glycemic index of commonly consumed carbohydrate foods in the Philippines. J. Funct. Foods 2010; 2:271-274.

[3] Purnomo H. Volatile Components of Coconut Fresh Sap, Sap Syrup and Coconut Sugar. ASEAN Food J. 2007; 14:45-49.

[4] Purnomo H \& Mufida LH. Sugar components of fresh sap and sap syrup of coconut. ASEAN Food J. 2004; 13:159-163.

[5] Purnomo H. Sugar Components of Coconut Sugar in Indonesia. ASEAN Food J. 1992; 7:200-201.

[6] Association of Official Analytical Chemists. Official Methods of Analysis of AOAC, $17^{\text {th }}$ Edition. (Maryland, U.S.A.: AOAC International, 2000).

[7] U.S. Food and Drug Administration. Bacteriological Analytical Manual. (AOAC International, 2001).

[8] McBurney MI \& Thompson LU. In vitro fermentabilities of purified fiber supplements. J. Food Sci. 1987; 54:347-350.

[9] Brunton NP, Gormley TR, \& Murray B. Use of alditol acetate derivatisation for the analysis of reducing sugars in potato tubers. Food Chem. 2007; 104:398-402.

[10] Ruiz-Matute Al, Rodriguez-Sanchez S, Sanz ML, \& Martinez-Castro I. Detection of adulterations of honey with high fructose syrups from inulin by GC analysis. J. Food Comp. Analysis 2010; 23:273276.

[11] Philippine National Standards for Coconut Sap Sugar. (Department of Trade and Industry, 2010).

[12] Codex Alimentarius. [7] Codex Standard for Sugars CODEX STAN 212-1999. 
[13] Coconut Sugar Philippines website. "Coconut Sugar Health Info." 2009. Retrieved June 14, 2011 from http://www.coconutsugarphilippines.com/ coconutsugarhealthinfo.php.
[14] Chen WJL, Anderson JW, \& Jenkins DJA. Propionate may mediate the hypocholesterolimic effects of certain soluble plant fibers in cholesterolfed rats. Proc. Soc. Exp. Biol. Med. 1984; 75:215-218. 